\title{
Herpes simplex virus type 2 and HIV disease progression: a systematic review of observational studies
}

Darrell Hoi-San Tan ${ }^{1,2,3,4^{*}}$, Kellie Murphy, ${ }^{4,5}$, Prakesh Shah ${ }^{4,6}$ and Sharon Lynn Walmsley ${ }^{2,3,4}$

\begin{abstract}
Background: Herpes simplex virus type 2 (HSV-2) is a common co-infection among HIV-infected adults that is hypothesized to accelerate HIV disease progression.

Methods: We searched Medline, EMBASE, relevant conference proceedings (2006-12) and bibliographies of identified studies without language restriction for cohort studies examining the impact of HSV-2 on highly active antiretroviral therapy-untreated HIV disease in adults. The exposure of interest was HSV-2 seropositivity or clinical/laboratory markers of HSV-2 activity. The primary outcome was HIV disease progression, defined as antiretroviral initiation, development of AIDS/opportunistic infection, or progression to CD4 count thresholds ( $\leq 200$ or $\leq 350$ cells $/ \mathrm{mm}^{3}$ ). Secondary outcomes included HIV plasma viral load and CD4 count.
\end{abstract}

Results: Seven studies were included. No definitive relationship was observed between HSV-2 seropositivity and time to antiretroviral initiation ( $n=2$ studies), $C D 4 \leq 350(n=1), C D 4 \leq 200(n=1)$, death $(n=1)$, viral load ( $n=6)$ or CD4 count $(n=3)$. Although two studies each observed trends towards accelerated progression to clinical AIDS/opportunistic infection in HSV-2 seropositives, with pooled unadjusted hazard ratio=1.85 (95\% Cl=1.12,3.06; $\left.\left.\right|^{2}=2 \%\right)$, most Ols observed in the study for which data were available can occur at high CD4 counts and may not represent HIV progression. In contrast, a single study HSV-2 disease activity found that the presence of genital HSV-2 DNA was associated with a 0.4 log copies/mL increase in HIV viral load.

Conclusions: Despite an observation that HSV-2 activity is associated with increased HIV viral load, definitive evidence linking HSV-2 seropositivity to accelerated HIV disease progression is lacking. The attenuating effects of acyclovir on HIV disease progression observed in recent trials may result both from direct anti-HIV activity as well as from indirect benefits of HSV-2 suppression.

Keywords: Herpes simplex virus, Human immunodeficiency virus, Disease progression, Viral load, CD4 count, Seropositivity, Systematic review

\section{Background}

Herpes simplex virus type $2(\mathrm{HSV}-2)$ is a common pathogen that co-infects over half of HIV-infected adults [1], and may accelerate HIV disease by increasing plasma HIV viral load [2,3]. Some authors therefore suggest that HIV-infected patients be routinely screened for

\footnotetext{
* Correspondence: darrell.tan@gmail.com

'Division of Infectious Diseases, St. Michael's Hospital, 30 Bond St. 4CC - Room 4-179, Toronto, ON M5B 1W8, Canada

${ }^{2}$ Division of Infectious Diseases, University Health Network, 585 University Ave. 13-N, Toronto, ON M5G 2N2, Canada

Full list of author information is available at the end of the article
}

HSV-2 antibodies, and that co-infected individuals be offered chronic suppressive HSV therapy [4]. Indeed, two recent clinical trials among HIV, HSV-2 co-infected adults in Sub-Saharan Africa have demonstrated a modest attenuation in HIV disease progression with the anti-HSV medication acyclovir 400mg twice daily $[5,6]$. Two potential mechanisms for this finding have been advanced. The leading hypothesis is that by suppressing HSV-2 activity, acyclovir reverses the adverse impact of HSV-2 co-infection on HIV disease progression. More recently, however, in vitro data have suggested that

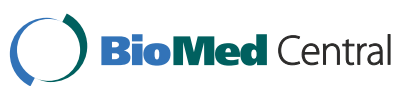


acyclovir may have direct anti-HIV activity $[7,8]$, raising the possibility that anti-HIV effects may have also contributed to the trial findings.

To further investigate these issues, and to inform the counseling of HIV patients regarding the impact of co-infection on their HIV disease, we undertook a systematic review of observational cohort studies addressing the impact of HSV-2 on longitudinal measures of HIV disease progression. The primary objective was to summarize the impact of HSV-2 co-infection on antiretroviral therapy (ART)-untreated HIV disease progression among HIV-1-infected adults. Secondary objectives were to summarize the relationship between HSV-2 coinfection (including both seropositivity and measures of HSV-2 disease activity) and HIV plasma viral load and CD4 count.

\section{Methods}

Methods of the analysis and inclusion criteria were specified in advance and documented in a protocol available from the authors.

\section{Study and participant criteria}

Cohort studies examining the impact of HSV-2 coinfection on progression of ART-untreated HIV disease over $\geq 6$ months, HIV plasma viral load, or CD4 count were considered for inclusion. Studies must have included HIV-1-infected adults not using ART (mono- or combination therapy). However, a single study including short-course zidovudine for the prevention of motherto-child HIV transmission (week 34-36 of pregnancy until delivery) was included, because this short duration of exposure was unlikely to impact on disease progression over the 18 month median duration of follow-up. Participants must not have been using chronic suppressive anti-HSV therapy (acyclovir, valacyclovir and/or famciclovir) or other agents with anti-HSV activity (eg. ganciclovir, valganciclovir, cidofovir, foscarnet).

\section{Exposure}

The exposure of interest was HSV-2 co-infection. Because HSV-2 is incurable and frequently asymptomatic, this exposure can only be accurately ascertained through HSV type-specific serologic assays that detect antibody to glycoprotein G. Studies using less accurate serologic assays such as those based on whole virus or crude antigen preparations were excluded.

Alternative laboratory measures of HSV-2 disease activity with good specificity were also examined, including viral culture and viral shedding detected by polymerase chain reaction $(\mathrm{PCR})$, but studies using clinical history only were excluded because such anamnestic methods are of limited sensitivity.

\section{Outcome measures}

The primary outcome of interest was HIV disease progression. Because multiple valid measures of this concept exist and have changed over time, it was important to include different definitions of this outcome and consider each one separately, including a) ART initiation b) development of AIDS or first opportunistic infection (OI), c) progression to CD4 count $\leq 200$ cells $/ \mathrm{mm}^{3}$, and d) progression to CD4 count $\leq 350$ cells $/ \mathrm{mm}^{3}$. Secondary outcomes were HIV plasma viral load and CD4 count since these are critical laboratory markers for assessing HIV disease progression. Since viral loads fluctuate around a stable 'set-point' in individual patients, the main viral load measures of interest were time-averaged viral loads collected over $\geq 6$ months, or changes in viral load at authordefined time points. The main CD4 count measure of interest was the rate of change per unit time. Withinpatient changes in viral load and CD4 count associated with HSV-2 disease activity over time were also collected.

\section{Search methods for identifying studies}

Eligible publications were identified through electronic searches of Medline (January 1950-April week 3, 2013) and EMBASE (1980-2013 week 16) followed by removal of duplicate citations. Details of the Medline search strategy are provided in Additional file 1. Manual searches of the following conference proceedings from 2006-2012 were also conducted: Conference on Retroviruses and Opportunistic Infections, International AIDS Society Conference on HIV Pathogenesis, Treatment and Prevention; IAS World AIDS Conference, Interscience Conference on Antimicrobial Agents and Chemotherapy, Infectious Diseases Society of America Annual Meeting, and the International Society for Sexually Transmitted Disease Research. Reference lists of identified articles were also used. No language restrictions were applied. We did not search grey literature or dissertation indices.

\section{Selection of studies and data extraction}

All publications and abstracts that appeared to meet eligibility criteria were retrieved. Two authors (DHST, KM) independently assessed studies for inclusion in an unblinded standardized manner, and independently extracted data onto standardized forms, with disagreements resolved by consensus and involvement of other authors. Information was extracted from each included study on: 1) characteristics of study participants, including geographic location, sex, baseline CD4 count, baseline HIV viral load, 2) methods of HSV-2 ascertainment, including details of laboratory assays as appropriate, and 3) outcome measures, including time-to-event data, CD4 counts, and viral load, along with the follow-up time for the study. Attempts to contact authors to supply missing data were made on up to three occasions; if 
information was not available, data were assumed to be missing at random.

\section{Assessment of risk of bias}

Assessment of risk of bias was performed for each study to explain heterogeneity in results and perform sensitivity analyses. A list of important study features that may impact on bias was developed by reviewing the STROBE statement and other published criteria $[9,10]$. This approach was used because a previously published systematic review of tools for assessing the quality and susceptibility to bias in observational studies was unable to identify a single obvious candidate tool for this purpose, and similarly references the STROBE statement as a valuable starting point for quality assessment [11]. The risk of bias for each study was assessed systematically using the criteria in Table 1. Assessments were not blinded to articles for feasibility reasons.

\section{Analysis}

The primary expected summary measure relating HIV disease progression to HSV-2 co-infection was the hazard ratio. Where appropriate, hazard ratios were pooled in meta-analyses using random effects models, with weighting of studies according to the DerSimonian-Laird method. Cochran's Q test was used to test for heterogeneity between studies at the 0.10 level of significance. The I-squared statistic was used to quantify the degree of heterogeneity. For viral load and CD4 count outcomes, meta-analysis was planned using the weighted mean difference, but available data were inappropriate for analysis due to differences in study methodology and reporting. Formal tests to assess for the possibility of publication bias were not performed given the variety of ways in which outcomes were reported. All statistical analyses were performed using Review Manager version 5. Data were synthesized descriptively when not appropriate for meta-analysis.

Subgroup analyses were planned to examine incident rather than prevalent HSV-2 infection, incident versus prevalent HIV infection, geographic region, HSV-1 coinfection, and use of any antiretrovirals. Sensitivity analyses were planned in which the results of studies would be considered in groups, according to the risk of bias.

\section{Results}

Studies included in the review

The electronic search strategy identified 1052 articles through MEDLINE and 1531 through EMBASE (Figure 1). Of these, 38 appeared to meet eligibility criteria. Two potentially eligible articles were identified from reference lists, and two more from conference proceedings. Of the resulting 42 studies, 7 were ultimately included (Table 2) [12-18]. Thirty-five papers were excluded because they were cross-sectional in design $(n=13)$, addressed a different research question $(n=7)$, included ART-treated

Table 1 Criteria for assessing the risk of bias in included studies ${ }^{a}$

\begin{tabular}{|c|c|c|c|}
\hline \multirow[t]{2}{*}{ Criterion } & \multicolumn{3}{|c|}{ Risk of bias } \\
\hline & Low & Moderate & High \\
\hline \multirow[t]{2}{*}{ Eligibility } & $\begin{array}{l}\text { Recruited from general HIV-infected population, } \\
\text { eg. HIV clinics }\end{array}$ & $\begin{array}{l}\text { - Recruited from moderately selected } \\
\text { population, eg. STI clinics }\end{array}$ & $\begin{array}{l}\text { Highly selected population } \\
\text { (eg. FSW, active GUD) }\end{array}$ \\
\hline & & & - Unclear selection criteria applied \\
\hline \multirow{2}{*}{$\begin{array}{l}\text { HSV-2 } \\
\text { ascertainment }\end{array}$} & High quality type-specific serology assay & - Culture-based diagnosis & - Methods unclear \\
\hline & - PCR assay & · Clinical diagnosis & \\
\hline \multirow{2}{*}{$\begin{array}{l}\text { Endpoint } \\
\text { ascertainment }\end{array}$} & Similar between groups & - Similar between groups & - Methods unclear \\
\hline & Regular timing & - Irregular timing & \\
\hline \multirow[t]{3}{*}{ Confounding } & Accounted for ART, and & - Some of these confounders & - None of these confounders \\
\hline & Accounted for acyclovir, and & accounted for & accounted for or unclear \\
\hline & Accounted for CD4/stage of HIV disease & & \\
\hline \multirow[t]{2}{*}{ Analysis } & Sample size or power calculation done, and & - No concerns with analysis & - Problems identified with analysis \\
\hline & No concerns with analysis & & \\
\hline \multirow[t]{2}{*}{ Attrition } & Minimal attrition $(<10 \%)$ and & - Moderate attrition (10-20\%) & . High attrition (>20\%) \\
\hline & Attrition explained & & Attrition not explained \\
\hline \multirow[t]{2}{*}{ OVERALL } & $\begin{array}{l}\text { Most items at low risk of bias, including both } \\
\text { HSV-2 ascertainment and confounding }\end{array}$ & $\begin{array}{l}\text { - Most items at low to moderate } \\
\text { risk of bias }\end{array}$ & - Most items at moderate risk of bias \\
\hline & $\begin{array}{l}\text { Not more than two items at moderate risk } \\
\text { of bias }\end{array}$ & - No item at high risk of bias & $\begin{array}{l}\text { - At least one item at high risk } \\
\text { of bias }\end{array}$ \\
\hline
\end{tabular}

${ }^{\mathrm{a}} \mathrm{FSW}$ = female sex workers; GUD = genital ulcer disease; STI = sexually transmitted infection. 


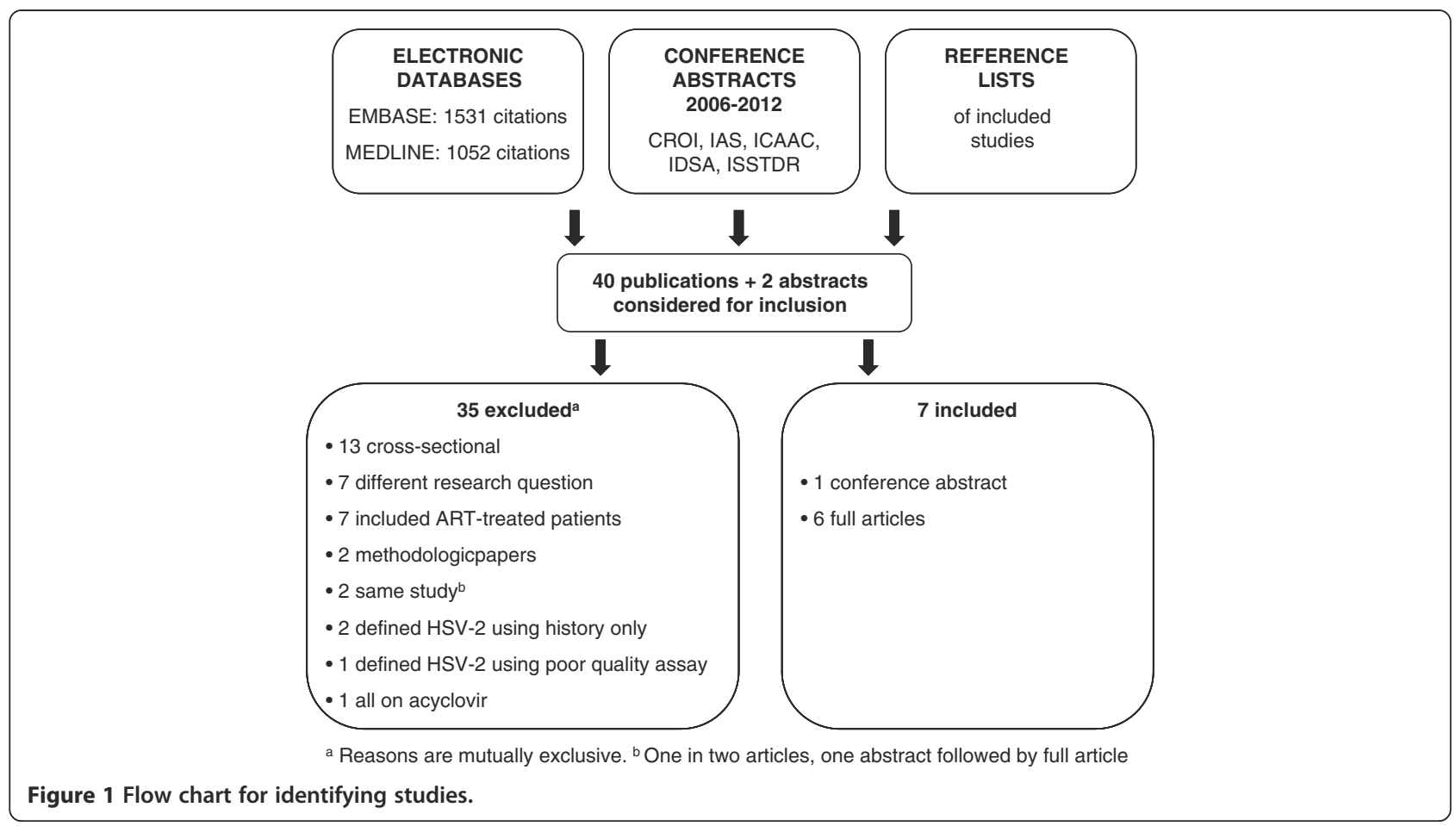

patients $(n=7)$ were methodologic in nature $(n=2)$, were duplicate publications $(n=2)$, used clinical history $(n=2)$ or a poor quality serologic assay $(n=1)$ to define HSV-2 status, or included only patients receiving acyclovir $(n=1)$.

\section{Assessment of risk of bias}

The quality of included studies was variable (Table 2). Eligibility criteria were generally appropriate and well described, with most included studies conducted among unselected cohorts of HIV-infected adults. All studies employing serology to ascertain HSV-2 status used high quality assays, although the timing of HSV-2 testing relative to the period of follow-up was unclear in one report [15]. The single study employing a marker of HSV2 disease activity in the analysis used HSV-2 polymerase chain rection (PCR) to detect the presence of reactivating virus in a cohort of HSV-2 seropositive participants [16]. Outcome assessments were general well performed, although their timing was irregular or unclear in some reports $[14,15]$. Several studies did not report on or adequately adjust for relevant confounders including antiHSV medications $[12,15,17,18]$, and baseline CD4 count [15]. No study included a formal sample size calculation, and attrition was inconsistently described, but analytic techniques were generally appropriate.

For studies at moderate or high risk of bias, a qualitative assessment was made regarding the likely direction of bias(es). For instance, studies failing to systematically account for anti-HSV medications may be biased towards the null $[12,15,17,18]$.

\section{Studies evaluating HSV-2 seropositivity Disease progression outcomes}

Four studies evaluated the relationship between HSV-2 seropositivity and HIV disease progression outcomes (Table 3). Two considered ART initiation as an endpoint, and neither observed an association with HSV-2 seropositivity; these studies were at moderate [12] and high [15] risk of bias respectively but the likely direction of this bias was difficult to ascertain. In addition, different definitions of ART were used, as shown. Data were therefore not appropriate for meta-analysis [12,15].

The latter of these studies also reported on the proportion of individuals reaching a CD4 count $\leq 350$ cells/ $\mathrm{mm}^{3}$ or $18 \%$ at various time points and found no difference according to HSV-2 serostatus [15]. A study among postpartum women in Kenya similarly reported no statistically significant relationship between HSV-2 and time to CD4 count $\leq 200$ cells $/ \mathrm{mm}^{3}$, nor a relationship with the time to death from any cause. There was moderate risk of bias towards the null in this study because of some acyclovir use [17]. Again, differences in the outcome definitions precluded meta-analysis.

Two studies considered AIDS or OI as endpoints: the Kenyan study described above [17], and an Italian study of HIV seroconverters at high risk of bias of uncertain impact [18]. Both used clinical endpoint definitions and each observed a trend towards an accelerated time to these events with HSV-2 seropositivity $[17,18]$. Metaanalysis was conducted to pool the univariate hazard ratios for clinical AIDS from the two studies, giving a 
Table 2 Characteristics of included studies and assessment of the risk of bias ${ }^{\mathrm{a}}$

\begin{tabular}{|c|c|c|c|c|c|c|c|c|c|c|c|c|c|c|}
\hline \multirow[t]{2}{*}{ Study } & \multicolumn{6}{|c|}{ Study Characteristics } & \multicolumn{8}{|c|}{ Assessment of the risk of bias } \\
\hline & Population & $\mathrm{N}^{\mathbf{b}}$ & $\%$ Male & $\begin{array}{l}\text { Baseline } \\
\text { CD4 }\end{array}$ & $\begin{array}{l}\text { Baseline } \\
\text { VL }\end{array}$ & $\begin{array}{l}\text { Follow- } \\
\text { up time }\end{array}$ & Eligibility & $\begin{array}{c}\text { HSV-2 } \\
\text { Ascertain-ment }\end{array}$ & Endpoints & Confoun-ding & Analysis & Attrition & OVERALL & $\begin{array}{l}\text { Impact } \\
\text { of bias }\end{array}$ \\
\hline $\begin{array}{l}\text { Barnabas } \\
2011\end{array}$ & Men, International & 88 & 100 & NR & NR & NR & Moderate & Low & Low & Moderate & Moderate & Moderate & Moderate & $\downarrow$ \\
\hline $\begin{array}{l}\text { Cachay } \\
2007\end{array}$ & $\begin{array}{l}\text { Male HIV seroconverters, } \\
\text { USA }\end{array}$ & 294 & 100 & 497 & 4.97 & 205 days & Low & Low & Low & Low & Moderate & Low & Low & N/A \\
\hline $\begin{array}{l}\text { Cachay } \\
2008\end{array}$ & $\begin{array}{l}\text { Male HIV seroconverters, } \\
\text { USA }\end{array}$ & 119 & 100 & 520 & 5.04 & 779 days & Low & Low & Moderate & Low & Moderate & Low & Low & N/A \\
\hline $\begin{array}{l}\text { Crum- } \\
\text { Cianflone } \\
2006\end{array}$ & USA & 367 & 92 & 499 & NR & NR & Low & Moderate & Moderate & High & Moderate & Moderate & High & $?$ \\
\hline $\begin{array}{l}\text { Nagot } \\
2008\end{array}$ & Women, Burkina Faso & 140 & 0 & 443 & 4.48 & $\begin{array}{c}12 \\
\text { weeks }\end{array}$ & Moderate & Low & Low & Low & Moderate & Low & Low & N/A \\
\hline $\begin{array}{l}\text { Roxby } \\
2011\end{array}$ & Pregnant women, Kenya & 296 & 0 & 422 & 4.75 & $\begin{array}{c}18 \\
\text { months }\end{array}$ & Moderate & Low & Low & Moderate & Moderate & Moderate & Moderate & $\downarrow$ \\
\hline $\begin{array}{l}\text { Suligoi } \\
2001\end{array}$ & HIV sero-converters, Italy & 380 & 78 & NR & NR & 7.8 years & Low & Low & Moderate & High & Moderate & High & High & $?$ \\
\hline
\end{tabular}

${ }^{\mathrm{a}}$ Median values are reported unless noted otherwise. When values were not reported for overall population, a weighted average was taken.

${ }^{\mathrm{b}} \mathrm{N}$ reported for patients included in relevant comparisons only.

'Assessed only for studies deemed at moderate or high risk of bias. N/A = not applicable (ie. study at low risk of bias), $\downarrow$ indicates bias towards null, ? indicates uncertain bias of direction. 
Table 3 Impact of HSV-2 seropositivity on HIV disease progression ${ }^{\text {a }}$

\begin{tabular}{|c|c|c|c|c|c|c|c|c|}
\hline \multirow[t]{2}{*}{ Study } & \multirow[t]{2}{*}{ Population } & \multirow[t]{2}{*}{$\mathrm{N}$} & \multirow{2}{*}{$\begin{array}{l}\text { HSV-2 } \\
\text { Ascertainment }\end{array}$} & \multicolumn{5}{|c|}{ Results } \\
\hline & & & & Outcome & HSV2 positive & $\begin{array}{l}\text { HSV2 } \\
\text { negative }\end{array}$ & Difference & Effect $^{b}$ \\
\hline Barnabas 2011 & $\begin{array}{l}\text { HIV } \\
\text { seroconverters, } \\
\text { Americas }\end{array}$ & 87 & Serology: Western Blot & $\begin{array}{l}\text { Initiation of } \\
\text { HAART }\end{array}$ & NR & NR & $\begin{array}{l}\mathrm{aHR}=1.3^{c_{i}} \\
(95 \% \mathrm{Cl}=0.5,3.2)\end{array}$ & $\leftrightarrow$ \\
\hline \multirow[t]{3}{*}{$\begin{array}{l}\text { Crum-Cianflone } \\
2006\end{array}$} & USA & 367 & Serology: Focus & $\begin{array}{l}\text { Time from HIV } \\
\text { diagnosis to } \\
\text { initiation of any } \\
\text { ART }^{\text {d }}\end{array}$ & $\begin{array}{l}18 \text { months } \\
\text { (range }=1,156)\end{array}$ & $\begin{array}{l}9 \text { months } \\
\text { (range }=1,96 \text { ) }\end{array}$ & $p=0.10$ & $\leftrightarrow$ \\
\hline & & 271 & & $\begin{array}{l}\text { Proportion with } \\
\text { CD } 4 \leq 350 \text { or } 18 \% \\
\text { at } 1 \text { year of } \\
\text { follow-up }\end{array}$ & $62 / 144=43 \%$ & $66 / 127=52 \%$ & $\begin{array}{l}O R=0.70 \\
p=0.15\end{array}$ & $\leftrightarrow$ \\
\hline & & 221 & & $\begin{array}{l}\text { Proportion with } \\
\text { CD } 4 \leq 350 \text { or } 18 \% \\
\text { at } 3 \text { years of } \\
\text { follow-up }\end{array}$ & $84 / 118=71 \%$ & $75 / 103=73 \%$ & $\begin{array}{l}O R=0.92 \\
p=0.88\end{array}$ & $\leftrightarrow$ \\
\hline \multirow[t]{3}{*}{ Roxby 2011} & $\begin{array}{l}\text { Postpartum } \\
\text { women, Kenya }\end{array}$ & 296 & Serology: Focus & $C D 4 \leq 200$ & $50 / 254=20 \%$ & $7 / 42=17 \%$ & $\begin{array}{l}\text { aHR }=1.16^{f},(95 \% \\
C l=0.52,2.56) \\
p=0.72\end{array}$ & $\leftrightarrow$ \\
\hline & & & & First Ol & $43 / 254=17 \%$ & $2 / 42=5 \%$ & $\begin{array}{l}\text { aHR }=3.83^{f},(95 \% \\
C l=0.93,15.83) \\
p=0.06\end{array}$ & Faster? \\
\hline & & & & Death & $17 / 254=7 \%$ & $2 / 42=5 \%$ & $\begin{array}{l}\text { aHR }=1.33^{f} \\
(95 \% \\
C I=0.32,6.05) \\
p=0.66\end{array}$ & $\leftrightarrow$ \\
\hline Suligoi 2001 & Italy & 380 & Serology: Pockit & AIDS & NR & NR & $\begin{array}{l}\mathrm{HR}=1.68,(95 \% \\
\mathrm{Cl}=1.19,2.37) \\
\text { Adjusted } \\
\mathrm{HR}=1.13,(95 \% \\
\mathrm{Cl}=0.76,1.70)\end{array}$ & Faster? \\
\hline
\end{tabular}

${ }^{\mathrm{a}} \mathrm{Cl}=$ confidence interval, HAART $=$ highly active antiretroviral therapy, $\mathrm{HR}=$ hazard ratio, $\mathrm{NR}=$ not reported, OI = Opportunistic infection, OR $=$ odds ratio.

${ }^{b}$ Arrows show directions of association with HSV-2; '?' denotes borderline statistical significance or clinically significant differences not meeting statistical significance.

${ }^{\mathrm{C}}$ Adjusted for adenovirus 5 immunity, region, circumcision status, age, race, HLA group, trial intervention assignment (vaccine / placebo).

Includes any ART (monotherapy, non-HAART combination therapy and HAART).

e Defined as CD4 count $<350$ cells $/ \mathrm{mm}^{3}$ or $18 \%$.

${ }^{f}$ Adjusted for baseline CD4 count.

${ }^{\text {g}}$ Adjusted for age at HIV seroconversion, exposure category, sex.

statistically significant pooled $\mathrm{HR}=1.85$ ( $95 \% \mathrm{CI}=1.12,3.06$; $\mathrm{n}=676$ participants; $I^{2}=2 \%$, Figure 2 ). However, this pooled analysis does not explicitly adjust for an important potential confounder, the stage of HIV disease at which individuals began observation. In the Kenyan study, an analysis adjusted only for baseline CD4 count produced an adjusted $\mathrm{HR}=1.16$ (95\% CI=0.52,2.56) [17], whereas the univariate hazard ratio from the Italian study, an inception cohort which inherently accounted for participants' date of HIV seroconversion, was 1.68 (95\% CI=1.19,2.37) [18]. Of note, it was not possible to conclusively exclude the possibility of some ART use in the latter study, in that it was conducted between 1983-1998 in Italy. Of further note, most (at least 44/51) of the OIs observed in the Kenyan study were conditions that can arise at any CD4 count including tuberculosis and zoster, which are

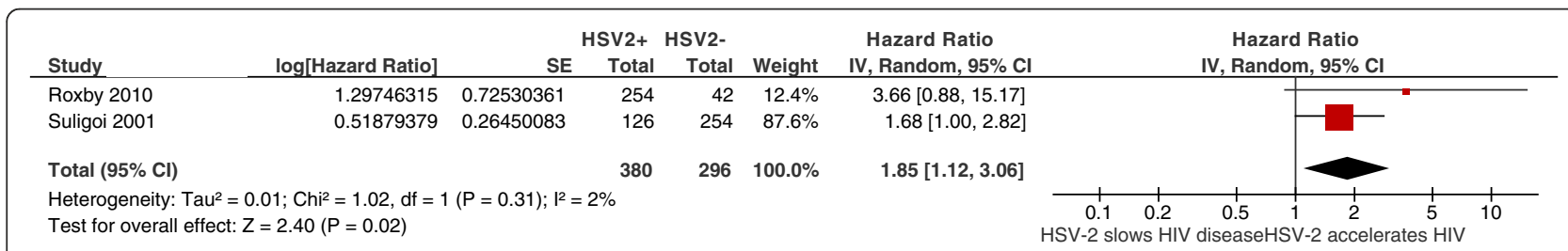

Figure 2 Forest plot of the impact of HSV-2 seropositivity on time to opportunistic infection/AIDS (unadjusted analysis). 
arguably less indicative of HIV disease progression than other AIDS-defining illnesses (ADI) [17]; data on the types of ADI in the Italian study were not available. In conclusion, while these two studies suggest a relationship between HSV-2 seropositivity on hastening progression to first OI or clinical AIDS, other available data do not support a relationship between HSV-2 serostatus and HIV disease progression overall.

\section{Plasma viral load}

Five studies compared plasma HIV viral load according to HSV-2 serostatus (Table 4). Of the four reporting on prevalent HSV-2 seropositivity, one used repeated measures regression models to assess viral loads over roughly half a year [13], two reported changes in viral load at fixed time points [15,17], and one used linear regression to assess the viral load set point, defined as the numeric average of the 8- and 12-week post-infection levels [12]. None observed a statistically significant association with increased HIV viral load, including the Kenyan study described above which did observe an accelerated time to OI [17]. Similarly, no effect on change in viral load was observed in the single study examining incident HSV-2 seropositivity, although the sample size was small with only 9 seroconverters [14].

\section{CD4 count}

Three studies examining the relationship between prevalent HSV-2 seropositivity and CD4 count reported conflicting results: a marginally slower rate of $\mathrm{CD} 4$ count decrease among HSV-2 infected American women in a study at moderate risk of bias towards the null [12], no difference in rates of CD4 count change in a Kenyan study at moderate risk of bias towards the null [17], and larger decreases in CD4 counts after fixed time points in an American study in which several methodologic issues may have had conflicting biases (Table 5) [15]. Incident HSV-2 seropositivity was associated with no change in CD4 counts based on one study [14].

\section{Studies evaluating HSV-2 activity}

There were no studies that met our eligibility criteria that described the relationship between HSV-2 disease activity and longitudinal measures of HIV disease progression. A single study examined the impact of HSV-2 activity on plasma HIV viral load among HSV-2 seropositive women in Burkina Faso, and observed modest increases of 0.4 log copies/mL associated with the presence of genital HSV-2 DNA over a 6-visit, 12-week follow-up period [16].

\section{Subgroup and sensitivity analyses}

Because most results could not be pooled in metaanalyses, quantitative subgroup and sensitivity analyses were not performed, and there were not enough studies available to provide meaningful subgroup analyses based on prespecified criteria (incident HSV-2, incident HIV, geographical location). No studies examined the impact of HSV-1 co-infection. Restricting the review to studies at low risk of bias left only three studies, which collectively described a lack of association between HSV-2 seropositivity and either HIV viral load or CD4 count $[13,14]$, but a positive association between laboratory

Table 4 Impact of HSV-2 seropositivity on viral load ${ }^{\mathrm{a}}$

\begin{tabular}{|c|c|c|c|c|c|c|c|c|}
\hline \multirow[t]{2}{*}{ Study } & \multirow[t]{2}{*}{ Population } & \multirow[t]{2}{*}{$\mathbf{N}$} & \multirow{2}{*}{$\begin{array}{l}\text { HSV2 } \\
\text { Ascertainment }\end{array}$} & \multicolumn{5}{|c|}{ Outcome: VIRAL LOAD (in $\log _{10}$ copies/mL) } \\
\hline & & & & Outcome & HSV2 pos & HSV2 neg & Difference & Effect $^{b}$ \\
\hline \multicolumn{9}{|c|}{ Studies in acute HIV seroconverters } \\
\hline $\begin{array}{l}\text { Barnabas } \\
2011\end{array}$ & $\begin{array}{l}\text { HIV } \\
\text { seroconverters, } \\
\text { Americas }\end{array}$ & 88 & Serology: WB & $\begin{array}{l}\text { VL setpoint (mean of } 8 \& \\
12 \text { week post-infection } V L)^{c}\end{array}$ & $\begin{array}{l}+0.3 \\
(95 \% \mathrm{Cl}=-0.1,0.7)\end{array}$ & Referent & $\begin{array}{l}\text { "No } \\
\text { significant } \\
\text { difference" }\end{array}$ & $\leftrightarrow$ \\
\hline $\begin{array}{l}\text { Cachay } \\
2007\end{array}$ & $\begin{array}{l}\text { Male HIV } \\
\text { seroconverters, } \\
\text { USA }\end{array}$ & 294 & $\begin{array}{l}\text { Serology: } \\
\text { Focus + WB }\end{array}$ & VL over median of $\sim 200$ days & NR & NR & $\begin{array}{l}\text { Difference } \\
\text { "close to zero" }\end{array}$ & $\leftrightarrow$ \\
\hline $\begin{array}{l}\text { Cachay } \\
2008\end{array}$ & $\begin{array}{l}\text { Male HIV } \\
\text { seroconverters, } \\
\text { USA }\end{array}$ & 9 & $\begin{array}{l}\text { Seroconversion } \\
\text { to HSV2 by WB }\end{array}$ & $\begin{array}{l}\text { Change in VL after vs. } \\
\text { before HSV-2 sero-conversion } \\
\text { over } 779 d\end{array}$ & $\begin{array}{l}+0.17 \\
\text { (range }-1.58,0.49)\end{array}$ & $\begin{array}{l}\text { Reference: Before } \\
\text { seroconversion }\end{array}$ & $p=0.57$ & $\leftrightarrow$ \\
\hline \multicolumn{9}{|c|}{ Studies in chronic HIV infection } \\
\hline \multirow{2}{*}{$\begin{array}{l}\text { Crum- } \\
\text { Cianflone } \\
2006\end{array}$} & \multirow[t]{2}{*}{ USA } & 271 & \multirow[t]{2}{*}{ Serology: Focus } & Change in VL at 1 year & +0.17 & +0.08 & $+0.1, p=0.61$ & $\leftrightarrow$ \\
\hline & & 221 & & Change in VL at 3 years & +0.46 & -0.09 & $+0.6, p=0.44$ & $\uparrow ?$ \\
\hline Roxby 2011 & $\begin{array}{l}\text { Postpartum } \\
\text { women, Kenya }\end{array}$ & 296 & Serology: Focus & $\begin{array}{l}\text { Change in VL over mean } \\
18 \text { months }\end{array}$ & NR & NR & No difference & $\leftrightarrow$ \\
\hline
\end{tabular}

${ }^{\mathrm{a}} \mathrm{Cl}=$ confidence interval, GUD = genital ulcer disease, $\mathrm{MSM}=$ men who have sex with men, $\mathrm{OR}=$ odds ratio, $\mathrm{SD}=\mathrm{standard}$ deviation, $\mathrm{VL}=$ viral load, WB $=$ Western Blot.

${ }^{\mathrm{b}}$ Arrows show directions of association with HSV-2; '?' denotes borderline statistical significance or clinically significant differences not meeting statistical significance.

${ }^{\mathrm{C}}$ Based in part on imputed data as $47 \%$ of $\mathrm{VL}$ observations missing. 
Table 5 Impact of HSV-2 seropositivity on CD4 count $^{\text {a }}$

\begin{tabular}{|c|c|c|c|c|c|c|c|c|}
\hline \multirow[t]{2}{*}{ Study } & \multirow[t]{2}{*}{ Population } & \multirow[t]{2}{*}{$\mathbf{N}$} & \multirow{2}{*}{$\begin{array}{l}\text { HSV2 } \\
\text { Ascertainment }\end{array}$} & \multicolumn{5}{|c|}{ Outcome: CD4 COUNT (in cells $/ \mathrm{mm}^{3}$ ) } \\
\hline & & & & Outcome & HSV2 pos & HSV2 neg & Difference & Effect $^{\text {b }}$ \\
\hline \multicolumn{9}{|c|}{ Studies in acute HIV seroconverters } \\
\hline Cachay 2008 & $\begin{array}{l}\text { Male HIV } \\
\text { seroconverters, } \\
\text { USA }\end{array}$ & 9 & $\begin{array}{l}\text { HSV2 } \\
\text { seroconversion } \\
\text { by WB }\end{array}$ & $\begin{array}{l}\text { Change in CD4 after vs } \\
\text { before HSV-2 } \\
\text { sero-conversion over } 779 \text { days }\end{array}$ & $\begin{array}{l}-44 \\
\text { (range }=-82,220)\end{array}$ & $\begin{array}{l}\text { Reference: Before } \\
\text { seroconversion }\end{array}$ & $p=0.36$ & $\leftrightarrow$ \\
\hline \multicolumn{9}{|c|}{ Studies in chronic HIV infection } \\
\hline \multirow[t]{2}{*}{$\begin{array}{l}\text { Crum-Cianflone } \\
2006\end{array}$} & USA & 271 & Serology: Focus & Change in CD4 at 1 year & -116 & +14 & $\begin{array}{l}-130 \\
p=0.003\end{array}$ & $\downarrow$ \\
\hline & & 221 & & Change in CD4 at 3 years & -227 & -85 & $\begin{array}{l}-142 \\
p=0.03\end{array}$ & $\downarrow$ \\
\hline Roxby 2011 & $\begin{array}{l}\text { Postpartum } \\
\text { women, Kenya }\end{array}$ & 296 & Serology: Focus & $\begin{array}{l}\text { Rate of change in CD4 over } \\
\text { mean } 18 \text { months }\end{array}$ & $-4.22 /$ month & $-3.42 /$ month & $\begin{array}{l}-0.8 / \text { month } \\
p=0.57\end{array}$ & $\leftrightarrow$ \\
\hline
\end{tabular}

${ }^{\mathrm{a}} \mathrm{Cl}=$ confidence interval, $\mathrm{IQR}=$ interquartile range, $\mathrm{NR}=$ not reported, $\mathrm{MSM}=$ men who have sex with men, WB = Western Blot.

${ }^{b}$ Arrows show directions of association with HSV-2; '?' denotes borderline statistical significance or clinically significant differences not meeting statistical significance.

confirmed presence of genital HSV-2 and increased plasma viral load [16].

\section{Discussion}

This systematic review did not identify conclusive evidence of an association between HSV-2 seropositivity and HIV disease progression, changes in plasma viral load, or CD4 cell count. Although two studies observed trends towards an accelerated progression to clinical AIDS or first OI $[17,18]$, most of the OIs observed in the study for which data were available can occur at high CD4 counts and may not represent progression of HIV [17]; further, compelling data linking HSV-2 seropositivity to other disease progression outcomes were lacking. One study found evidence that HSV-2 disease activity, defined as the presence of genital HSV-2 using PCR, is associated with increased viral load among HSV-2 seropositive individuals.

These observations must be considered in light of unequivocal data from interventional studies linking antiHSV medications to decreased HIV viral loads and attenuated disease progression. In a meta-analysis of seven randomized trials of acyclovir or valacyclovir among HAART-untreated, HIV, HSV-2 co-infected persons, the summary treatment effect for HSV-2 suppression on plasma HIV RNA was $-0.33 \log$ copies $/ \mathrm{mL}$ $(95 \% \mathrm{CI}=-0.56,-0.10)$ [19]. Further, this effect appears to be dose-responsive; stratification by drug demonstrated greater decreases in viral load with valacyclovir than acyclovir in the meta-analysis [19]. A meta-analysis from the pre-HAART era suggested that $>3200 \mathrm{mg}$ per day of acyclovir offered a significant survival benefit (hazard ratio, HR for mortality $=0.78$, 95\% confidence interval, $\mathrm{CI}=0.65,0.93$ ) [20], but it is unclear whether the improved survival was only related to eradication of herpesviruses (including HSV and CMV) or whether there could have been a secondary impact on HIV replication. Most recently, in the Partners in Prevention HSV/HIV Transmission Study of acyclovir $400 \mathrm{mg}$ twice daily, the HR for the composite primary endpoint of CD4 count $\leq 200$ cells $/ \mathrm{mm}^{3}$, antiretroviral initiation, or death from non-traumatic causes, was 0.84 (95\% $\mathrm{CI}=0.71,0.98)$ [6]. In a similar trial from the Rakai district of Uganda, the composite primary endpoint was slightly different (CD4 count $\leq 250$ cells $/ \mathrm{mm}^{3}$ or the occurrence of any WHO stage 4 clinical event not including esophageal candidiasis), and the HR associated with acyclovir use was $0.75(95 \% \mathrm{CI}=0.58,0.99)$ [5].

Indirect benefits of HSV-2 suppression are thought to primarily underlie these effects, and the observation of increased HIV viral load with HSV-2 disease activity in the Burkina Faso study supports this hypothesis [16]. But how might these findings be reconciled with the lack of convincing evidence of an effect of HSV-2 seropositivity on markers of HIV disease progression observed in this review? One explanation may be that all HSV-2 serology assays have limited sensitivity in early infection $[21,22]$, and no studies repeated testing on seronegative participants to test for seroconversion. However, the magnitude of this effect should be minimal, given the reported incidence of HSV-2 in HIV-infected populations of 1.8 to 7.3 per 100 person-years [14,23]. A more plausible hypothesis is that considering only HSV-2 serostatus ignores the duration and activity of HSV-2 infection. Since the natural history of HSV-2 is characterized by a decreasing frequency of reactivations over time [24-27], overrepresentation of individuals with longstanding infection may produce HSV-2 seropositive cohorts with relatively inactive HSV-2. The magnitude of HIV upregulation by HSV-2 may instead depend on the degree of HSV-2 activity and be greatest during symptomatic herpes, as has been observed elsewhere [28]. Studies of 
HSV-2 seropositivity cannot distinguish between periods of viral latency and reactivation, such that any impact of HSV-2 activity on HIV replication may have been diluted in some of the studies we included. In support of this notion, symptomatic genital ulcer disease of any etiology has been linked to accelerated HIV disease progression $[2,17,29]$. It is also likely that the positive relationship between HIV viral load and HSV-2 activity is partially confounded by HIV-related immunosuppression.

In contrast to the $0.4 \log$ copies $/ \mathrm{mL}$ increase in viral load associated with HSV-2 activity in the Burkinabé study [16], a recent randomized trial observed larger viral load decreases of $-1.23 \log$ copies/mL using valacyclovir $1.5 \mathrm{~g}$ twice daily [30]. Taken together, these observations suggest that reversing HSV-2 associated increases in HIV viral load may not be the only mechanism by which such drugs attenuate HIV. Direct antiretroviral effects of acyclovir and related drugs may also contribute, as have been observed in vitro by two independent groups $[7,8]$. Arguing against this possibility, however, an evaluation of $168 \mathrm{HIV}$ infected clinical trial participants receiving either acyclovir $400 \mathrm{mg}$ twice daily or valacyclovir $500 \mathrm{mg}$ twice daily for 8-104 weeks failed to identify the V75I reverse transcriptase mutation that confers acyclovir resistance most commonly observed in vitro [31]. The purported explanation for this negative finding is the considerably lower concentrations of acyclovir achieved in the clinical setting compared with the laboratory studies. Still another possibility is that acyclovir could attenuate HIV disease progression by decreasing HSV-2-related immune activation, although two studies have recently shown no benefit of valacyclovir on a variety of inflammatory markers [32,33]. Further data are needed to clarify the relationship between HSV-2, anti-herpes medications and HIV viral load.

Strengths of this systematic review include our broad, multi-modality search strategy and the lack of language restrictions. There are also limitations that warrant consideration, and the robustness of our conclusions is dependent on the available evidence. First, few studies addressed our primary research question, restricting our ability to quantify the impact of HSV-2 seropositivity on HIV disease progression. Second, the measures used to define HSV-2 seropositivity and HSV-2 activity differed between studies. Although most type-specific serology assays have high, comparable levels of sensitivity and specificity when compared against the Western Blot gold standard, uncertainty regarding the optimal cutoff values in different populations and limitations of all assays in detecting early HSV-2 seroconversion may result in misclassification [34]. Third, our assessment of the risk of study bias was necessarily subjective. However, we systematically applied criteria based on the STROBE statement as has been advised elsewhere, because of the lack of a single obvious candidate tool for this purpose in systematic reviews of observational studies [11]. Fourth, differences in study populations and HIV clades may explain some observed differences between studies. Finally, inadequate control for confounding by variables such as anti-HSV drug use could have biased studies towards the null; further, no study systematically excluded HIV long-term non-progressors.

\section{Conclusions}

This systematic review found no definitive evidence that HSV-2 seropositivity is associated with accelerated HIV disease progression in HAART-untreated persons, and modest evidence that HSV-2 disease activity is associated with increased HIV viral load. Attenuating effects of acyclovir on HIV disease progression observed in recent trials may result both from direct anti-HIV activity as well as from indirect benefits of HSV-2 suppression. Further research is needed to clarify the exact mechanisms by which HIV, HSV-2 and drugs like acyclovir interact.

\section{Additional files}

Additional file 1: "Medline search strategy", is a Microsoft Word file (extension .docx) containing details of the strategy used for searching that electronic database.

\section{Competing interests}

The authors have no competing interests to declare.

\section{Authors' contributions}

DT and SW conceived the study idea; DT designed the protocol, performed the analyses and wrote the original version of the manuscript; DT and KM performed the literature review and extracted relevant data; PS provided support regarding study design and analysis; all authors provided input into and approved the final version of the manuscript.

\section{Acknowledgements}

During the conduct of this work Dr. Darrell Tan was supported by fellowships from the Canadian HIV Trials Network and the Canadian Institutes of Health Research, and Dr. Sharon Walmsley was supported by a career scientist award from the Ontario HIV Treatment Network. The authors are grateful to Drs. Nancy Crum-Cianflone and Alison Roxby for their helpful correspondence regarding their work during the preparation of this systematic review.

\section{Author details}

${ }^{1}$ Division of Infectious Diseases, St. Michael's Hospital, 30 Bond St. 4CC - Room 4-179, Toronto, ON M5B 1W8, Canada. 'Division of Infectious Diseases, University Health Network, 585 University Ave. 13-N, Toronto, ON M5G 2N2, Canada. ${ }^{3}$ Division of Infectious Diseases, University of Toronto, 200 Elizabeth St, Toronto, ON M5G 2C4, Canada. ${ }^{4}$ Institute of Health Policy, Management and Evaluation, University of Toronto, 155 College St., Suite 425, Toronto, ON M5T 3M6, Canada. ${ }^{5}$ Department of Maternal Fetal Medicine, Mount Sinai Hospital, 600 University Avenue, Toronto, ON M5G 1X5, Canada. ${ }^{6}$ Department of Pediatrics, University of Toronto, 600 University Ave., Room 775-A, Toronto, ON M5G 1X5, Canada.

Received: 26 April 2013 Accepted: 21 October 2013

Published: 28 October 2013 


\section{References}

1. Romanowski B, Myziuk LN, Walmsley SL, Trottier S, Singh AE, Houston S, Joffe M, Chiu I: Seroprevalence and risk factors for Herpes Simplex virus infection in a population of HIV-infected patients in Canada. Sex Transm Dis 2008, 36:165-169.

2. Gray RH, Li X, Wawer MJ, Serwadda D, Sewankambo NK, Wabwire-Mangen F, Lutalo T, Kiwanuka N, Kigozi G, Nalugoda F, et al: Determinants of HIV-1 load in subjects with early and later HIV infections, in a general-population cohort of Rakai, Uganda. J Infect Dis 2004, 189:1209-1215.

3. Lyles RH, Munoz A, Yamashita TE, Bazmi H, Detels R, Rinaldo CR, Margolick JB, Phair JP, Mellors JW: Natural history of human immunodeficiency virus type 1 viremia after seroconversion and proximal to AIDS in a large cohort of homosexual men. Multicenter AIDS Cohort Study. J Infect Dis 2000, 181:872-880.

4. Strick $L B$, Wald $A$, Celum C: Management of herpes simplex virus type 2 infection in HIV type 1-infected persons. Clin Infect Dis 2006, 43:347-356.

5. Reynolds SJ, Makumbi F, Newell K, Kiwanuka N, Ssebbowa P, Mondo G, Boaz I, Wawer MJ, Gray RH, Serwadda D, et al: Effect of daily aciclovir on HIV disease progression in individuals in Rakai, Uganda, co-infected with HIV-1 and herpes simplex virus type 2: a randomised, double-blind placebo-controlled trial. Lancet Infect Dis 2012, 12:441-448.

6. Lingappa JR, Baeten JM, Wald A, Hughes JP, Thomas KK, Mujugira A, Mugo N, Bukusi EA, Cohen CR, Katabira E, et al: Daily aciclovir for HIV-1 disease progression in people dually infected with HIV-1 and herpes simplex virus type 2: a randomised placebo-controlled trial. Lancet 2010 375:824-833.

7. McMahon MA, Siliciano JD, Lai J, Liu JO, Stivers JT, Siliciano RF, Kohli RM: The antiherpetic drug acyclovir inhibits HIV replication and selects the V75I reverse transcriptase multidrug resistance mutation. J Biol Chem 2008, 283:31289-31293.

8. Lisco A, Vanpouille C, Tchesnokov EP, Grivel JC, Biancotto A, Brichacek B, Elliott J, Fromentin E, Shattock R, Anton P, et al: Acyclovir is activated into a HIV-1 reverse transcriptase inhibitor in herpesvirus-infected human tissues. Cell Host Microbe 2008, 4:260-270.

9. von Elm E, Altman DG, Egger M, Pocock SJ, Gotzsche PC, Vandenbroucke JP: The Strengthening the Reporting of Observational Studies in Epidemiology (STROBE) statement: guidelines for reporting observational studies. Ann Intern Med 2007, 147:573-577.

10. Vandenbroucke JP, von Elm E, Altman DG, Gotzsche PC, Mulrow CD, Pocock SJ, Poole C, Schlesselman JJ, Egger M: Strengthening the Reporting of Observational Studies in Epidemiology (STROBE): explanation and elaboration. Ann Intern Med 2007, 147:W163-W194.

11. Sanderson S, Tatt ID, Higgins JP: Tools for assessing quality and susceptibility to bias in observational studies in epidemiology: a systematic review and annotated bibliography. Int J Epidemiol 2007, 36:666-676

12. Barnabas RV, Wasserheit JN, Huang $Y$, Janes H, Morrow R, Fuchs J, Mark KE, Casapia M, Mehrotra DV, Buchbinder SP, et al: Impact of herpes simplex virus type 2 on HIV-1 acquisition and progression in an HIV vaccine trial (the Step study). J Acquir Immune Defic Syndr 2011, 57:238-244.

13. Cachay ER, Frost SDW, Richman DD, Smith DM, Little SJ: Herpes simplex virus type 2 infection does not influence viral dynamics during early HIV-1 infection [see comment]. J Infect Dis 2007, 195:1270-1277.

14. Cachay ER, Frost SDW, Poon AFY, Looney D, Rostami SM, Pacold ME, Richman DD, Little SJ, Smith DM: Herpes simplex virus type 2 acquisition during recent HIV infection does not influence plasma HIV levels. J Acquir Immune Defic Syndr 2008, 47:592-596.

15. Crum-Cianflone N, Hale B, Truett A, Utz G, Chun H, Pope B, Burgi A, Medina S, Brandt C, Furtek K, et al: The effect of herpes simplex virus 2 (HSV2) co-infection in HIV-infected persons on CD4 counts, HIV viral load, and time to antiretroviral medications. In 44th Annual Meeting of IDSA: 12-15 October 2006; Abstract 895. Toronto, Canada: Alexandria: Infectious Diseases Society of America; 2006.

16. Nagot N, Ouedraogo A, Konate I, Weiss HA, Foulongne V, Defer MC, Sanon A, Becquart P, Segondy M, Sawadogo A, et al: Roles of clinical and subclinical reactivated herpes simplex virus type 2 infection and human immunodeficiency virus type 1 (HIV-1)-induced immunosuppression on genital and plasma HIV-1 levels. J Infect Dis 2008, 198:241-249.

17. Roxby AC, Drake AL, John-Stewart G, Brown ER, Matemo D, Otieno PA, Farquhar C: Herpes simplex virus type 2, genital ulcers and HIV-1 disease progression in postpartum women. PLoS One 2011, 6:e19947.
18. Italian Seroconversion S, Suligoi B, Dorrucci M, Volpi A, Andreoni M, Pezzotti P, Rezza G: Absence of an effect of herpes simplex virus type 2 infection on HIV disease progression: data from a cohort of HIV-positive individuals with known date of seroconversion. AIDS 2001, 15:133-135.

19. Ludema C, Cole SR, Poole C, Chu H, Eron JJ: Meta-analysis of randomized trials on the association of prophylactic acyclovir and HIV-1 viral load in individuals coinfected with herpes simplex virus-2. AIDS 2011 25:1265-1269.

20. Ioannidis JP, Collier AC, Cooper DA, Corey L, Fiddian AP, Gazzard BG Griffiths PD, Contopoulos-loannidis DG, Lau J, Pavia AT, et al: Clinical efficacy of high-dose acyclovir in patients with human immunodeficiency virus infection: a meta-analysis of randomized individual patient data. J Infect Dis 1998, 178:349-359.

21. Ashley-Morrow R, Krantz E, Wald A: Time course of seroconversion by HerpeSelect ELISA after acquisition of genital herpes simplex virus type 1 (HSV-1) or HSV-2. Sex Transm Dis 2003, 30:310-314.

22. Ashley RL, Militoni J, Lee F, Nahmias A, Corey L: Comparison of Western blot (immunoblot) and glycoprotein G-specific immunodot enzyme assay for detecting antibodies to herpes simplex virus types 1 and 2 in human sera. J Clin Microbiol 1988, 26:662-667.

23. Ramaswamy M, Sabin C, McDonald C, Smith M, Taylor C, Geretti AM: Herpes simplex virus type 2 (HSV-2) seroprevalence at the time of HIV-1 diagnosis and seroincidence after HIV-1 diagnosis in an ethnically diverse cohort of HIV-1-infected persons. Sex Transm Dis 2006, 33:96-101.

24. Benedetti J, Corey L, Ashley R: Recurrence rates in genital herpes after symptomatic first-episode infection. Ann Intern Med 1994, 121:847-854.

25. Benedetti JK, Zeh J, Corey L: Clinical reactivation of genital herpes simplex virus infection decreases in frequency over time. Ann Intern Med 1999, 131:14-20.

26. Engelberg R, Carrell D, Krantz E, Corey L, Wald A: Natural history of genital herpes simplex virus type 1 infection. Sex Transm Dis 2003, 30:174-177.

27. Wald A, Zeh J, Selke S, Ashley RL, Corey L: Virologic characteristics of subclinical and symptomatic genital herpes infections. N Engl J Med 1995, 333:770-775.

28. Mole L, Ripich S, Margolis D, Holodniy M: The impact of active herpes simplex virus infection on human immunodeficiency virus load. J Infect Dis 1997, 176:766-770

29. Aumakhan B, Gaydos CA, Quinn TC, Beyrer C, Benning L, Minkoff H, Merenstein DJ, Cohen M, Greenblatt R, Nowicki M, et al: Clinical reactivations of herpes simplex virus type 2 infection and human immunodeficiency virus disease progression markers. PLOS One 2010, 5:1-7.

30. Mugwanya K, Baeten JM, Mugo NR, Irungu E, Ngure K, Celum C: High-dose valacyclovir HSV-2 suppression results in greater reduction in plasma HIV-1 levels compared with standard dose acyclovir among HIV-1/HSV-2 coinfected persons: a randomized, crossover trial. J Infect Dis 2011, 204:1912-1917.

31. Baeten JM, Lingappa J, Beck I, Frenkel LM, Pepper G, Celum C, Wald A, Fife $\mathrm{KH}$, Were $\mathrm{E}$, Mugo $\mathrm{N}$, et al: Herpes simplex virus type 2 suppressive therapy with acyclovir or valacyclovir does not select for specific HIV-1 resistance in HIV-1/HSV-2 dually infected persons. J Infect Dis 2011, 203:117-121.

32. Roxby AC, Liu AY, Drake AL, Kiarie JN, Richardson B, Lohman-Payne BL, John-Stewart GC, Wald A, De Rosa S, Farquhar C: Short communication: T cell activation in HIV-1/herpes simplex virus-2-coinfected Kenyan women receiving valacyclovir. AIDS Res Hum Retroviruses 2013, 29:94-98.

33. Yi TJ, Walmsley S, Szadkowski L, Raboud J, Rajwans N, Shannon B, Kumar S, Kain KC, Kaul R, Tan DHS: A randomized controlled pilot trial of valacyclovir for attenuating inflammation and immune activation in HIV/Herpes simplex virus 2-coinfected adults on suppressive antiretroviral therapy. Clin Infect Dis 2013. epub ahead of print.

34. Ashley-Morrow R, Nollkamper J, Robinson NJ, Bishop N, Smith J: Performance of focus ELISA tests for herpes simplex virus type 1 (HSV-1) and HSV-2 antibodies among women in ten diverse geographical locations. Clin Microbiol Infect 2004, 10:530-536.

\section{doi:10.1186/1471-2334-13-502}

Cite this article as: Tan et al:: Herpes simplex virus type 2 and HIV disease progression: a systematic review of observational studies. BMC Infectious Diseases 2013 13:502. 